\title{
First results on physico-chemical status and bathymetry of lakes in Ramaroshan Wetland, Far-West Nepal
}

\author{
Tarka Bahadur Chalaune*, Alina Dangol, Jiban Sharma, Chhatra Mani Sharma
}

Central Department of Environmental Science, Tribhuvan University, Kathmandu, Nepal

\begin{abstract}
This study investigates the bathymetry of three major lakes and the water quality of nine lakes at Ramaroshan Lake Complex Area (RLCA), Far-Western Nepal. Lakes were surveyed based on line transects using Echosounder (depth measuring gauge) and GPS to collect the data for bathymetry. Water samples were collected from 43 sites of nine lakes, considering the land use patterns, anthropogenic activities, inlets, and outlets. Twenty physico-chemical parameters were analyzed to know the water characteristics and pollution level. The bathymetry map showed that Jingale is the deepest lake $(44 \mathrm{~m})$, followed by Batula (15 $\mathrm{m})$ and Mathillo Dhaune $(9.5 \mathrm{~m})$. There was no significant spatial variability in the concentration of physicochemical parameters among the sampling sites. The mean concentrations of cations and anions were in the order of $\mathrm{Ca}^{2+}>\mathrm{Mg}^{2+}>\mathrm{Na}^{+}>\mathrm{K}^{+}$, and $\mathrm{HCO}_{3}>\mathrm{Cl}^{-}>\mathrm{SO}_{4}{ }^{2-}>\mathrm{PO}_{4}{ }^{2-}>\mathrm{NO}_{3}{ }^{-}$, respectively. Principal component analysis (PCA) and cluster analysis (CA) techniques were applied to assess the influence of pollution levels and their controlling mechanism. PCA showed $79.89 \%$ of the cumulative variance with > 1.26 Eigenvalue. Similarly, CA showed that Jingale Lake (in cluster 2) sites were less polluted than other sampling sites. Piper diagram concluded that there was a dominance of mixed water type belonging to Ca$\mathrm{Mg}-\mathrm{Cl}$ compared to $\mathrm{Ca}-\mathrm{HCO}_{3}$. Furthermore, the Water Quality Index (WQI) value of the lakes in the study area was 27 indicating good water quality (slightly polluted).
\end{abstract}

Keywords: Bathymetry, far-western region, Nepal, Ramaroshan Lake Complex Area, water quality

\section{Introduction}

Wetlands are the most productive environment providing many ecosystem services; biodiversity conservation, recreation and tourism, carbon sequestration, etc. Besides, wetlands are the source of sustainable livelihoods, support human wellbeing through eco-tourism activities and wetland productivity such as fisheries and paddy production. Groundwater recharge, sediment and nutrient retentions and export, and flood control are the other ecosystem services provided by wetlands (Cheng et al., 2014; Hushulong, 2012; Lamsal et al., 2015; Zedler \& Kercher, 2005). Wetlands are helpful in achieving Sustainable Development Goals (SDGs) related to water, climate, ecosystems, and human wellbeing. However, wetland ecosystems are the most threatened natural resources; they have continuously been degrading by both natural as well as anthropogenic activities such as unsustainable grazing and fishing (Gibbs, 2000). Moreover, wetlands are facing several other threats such as pollution, eutrophication, invasion, sedimentation, and overexploitation of natural resources, human encroachment, and climate change (Sharma et al., 2005).
Morphometry represents the lake form characteristics and their basin, which depends upon the topography and geological events occurring in that area (Awulachew, 2006). Morphology is the key indicators to determine and identify the environmental status of wetlands (Moses et al., 2011). The morphometry characteristics and water quality can influence the physico-chemistry, distribution of aquatic life, littoral zone development and ecosystem productivity, hydrodynamics, food web structure, and biogeochemical cycle of lakes. Shallow and small lakes have comparatively lower nutrient recycling and regeneration rates and more sensitive to environmental stressors compare to a large lake (Hakanson, 2005; Moses et al., 2011; Noges, 2009; Stefanidis \& Papastergiadou, 2012). Also, the water storage dynamics influence the hydrological cycle, regional environment, and climate (Qiao et al., 2019). The annual variations in the weather and global climate change have an unprecedental effect on the physical characters and biological properties of the lake (George et al., 2007; Schindler et al., 1996).

\footnotetext{
* Corresponding author: tarkac99@gmail.com
} 
In Nepal, approximately 5,385 lakes have been recorded, of which 419 lakes are located in the mid-hills between $500 \mathrm{~m}$ to 2,999 m (Bhuju et al., 2013). Ramaroshan Lake Complex Area (RLCA) is an aesthetically, culturally and ecologically important area that is facing several threats mainly caused by anthropogenic activities such as unsustainable grazing, fishing, foraging, and fodder collection. (DOF, 2017) has recorded only seven lakes in this area, categorizing four lakes as 'good' and the remaining three as 'degrading' lakes. However, this area is popularly known as Barha Banda Athbara Khanda (means 12 lakes and 18 patches of grasslands). Due to the high ecotourism potential of the area, the Government of Nepal (GoN) started to develop infrastructures without conducting scientific research and environmental impact assessment. In addition, this area has been declared as a potential Ramsar Site by the local government, which covers an area of 3051.29 ha, including 2954.26 ha forest, 55.05 grasslands (patan), 30 ha lakes and 11.98 ha river (DOF, 2017). The GoN has already included Ramaroshan Area as one of the top 100 tourist destinations of Nepal for the promotion of tourism year in 2019 (Upadhayaya, 2019). However, the scientific study related to inventory, morphometry of lake, understanding of the status of the water quality and overall wetland ecology is still lacking in the RLCA.

The purpose of this study is to provide fundamental information regarding the morphometric and water quality parameters of the selected lakes in RLCA, which can support the government in developing a scientific management plan for the sustainable and wise use of natural resources in the near future.

\section{Materials and Methods}

Study area

Ramaroshan Lake Complex Area (RLCA) is a mid-hill wetland in a remote area of Far-western Nepal extending from 1401 to $3792 \mathrm{~m}$ asl (Fig. 1). The mean annual temperature varies from $30^{\circ} \mathrm{C}$ to $1^{\circ} \mathrm{C}$, and precipitation ranges between $1486-1739 \mathrm{~mm}$ (DOF, 2017). The geological formations of RLCA are Sallyani Gad and Kalikot formation, similarly the rock types in this area consist of Granite, Gneisses, Limestone and Schist (Dahal \& Dahal, 2017). RLCA provides the habitat for 112 flowering plants and 12 species of cryptograms, eight species of wetland-dependent birds, including migratory species (Poudel \& Adhikari, 2020). Similarly, the study area harbors 15 species of mammals, 13 species of butterflies (Karki et al., 2002), RLCA provides potential water resources for the benefit of diverse ecosystem services, support local livelihoods, drinking, irrigation, and energy production. It is the headwater of the Kailash River, which provides ecosystem services in large scales and supports downstream people.

\section{Sampling and Analysis}

The lake bathymetry (depth, volume and area) was obtained by line transects ( $\mathrm{N}$ shape) method using an Echosounder (depth measuring gauge; Plastimo echotest-II) accompanied by GPS points (Garmin Venture SC) at each sampling point. Bathymetry measurements were taken from three major lakes, viz., Jingale, Batula and Mathillo Dhaune. The number of sampling points varied for different lakes depending on the size of the lakes; for example, 149 sampling points were taken from Jingale, 42 from Batula, and 26 from Mathilo Dhaune, respectively. Finally, bathymetry maps of these three lakes were produced with the help of ArcGIS 10.4 and Surfer Pro by Golden software 11 .

Altogether 43 water samples were collected from the nine lakes in January 2020. Sampling sites were established to represent the overall variability, such as inlets, outlets, land covers, human disturbances, the middle and the deepest parts (Fig. 1). The water samples were collected in a $1 \mathrm{~L}$ highdensity polyethylene (HDPE) bottle after rinsing three times by the lake water following standard procedures as described in Eaton et al. (2005) and Sharma et al. (2012). The in-situ measurement of physico-chemical parameters such as temperature, $\mathrm{pH}$, electrical conductivity (EC), and total dissolved solids (TDS) was done by multi-parameter instrument HANA, dissolved oxygen (DO) by DO meter, alkalinity and free $\mathrm{CO}_{2}$ by titration method, and transparency by using a Secchi disc. For the laboratory analysis, water samples were filtered using $0.45 \mathrm{~mm}$ Millipore filters with the hand-operated vacuum pump, and samples were acidified with $2 / 3$ drops of conc. Nitric acid and sulphuric acid in the field for maintaining $\mathrm{pH} 2$ for the measurement of cations and anions, respectively. All water samples were maintained at $4^{\circ} \mathrm{C}$ before they reach the laboratory.

The water quality index (WQI) of lakes was calculated by the following equation (Bora \& Goswami, 2017; Brown et al., 1972).

$$
W Q I=\sum_{i=1}^{n} Q i W i / \sum_{i=1}^{n} W i \ldots \ldots \ldots \ldots \ldots \ldots \ldots \text { (1) }
$$

where, Qi is used for rating value of $i^{\text {th }}$ parameters and calculated as $Q i=\left[\frac{V i-V o}{S i-V o}\right]$; vi is the observed value of $i^{\text {th }}$ parameters, $\mathrm{Si}$ is the standard permissible value of $i^{\text {th }}$ parameters, and $\mathrm{V}_{0}$ is the ideal value (zero for all parameters except pH: 7.0 and DO: $14.6 \mathrm{mg} / \mathrm{L}$ ) prescribed by BIS (2012); wi unit weight assigned by $i^{\text {th }}$ parameters and was calculated as $W i=\frac{K}{S i}$ and $K=1 / \sum_{i}^{n} \frac{1}{S i}$ where, $\mathrm{K}$ is the constant of proportionality, which is determined from the condition $K=$ 1. 


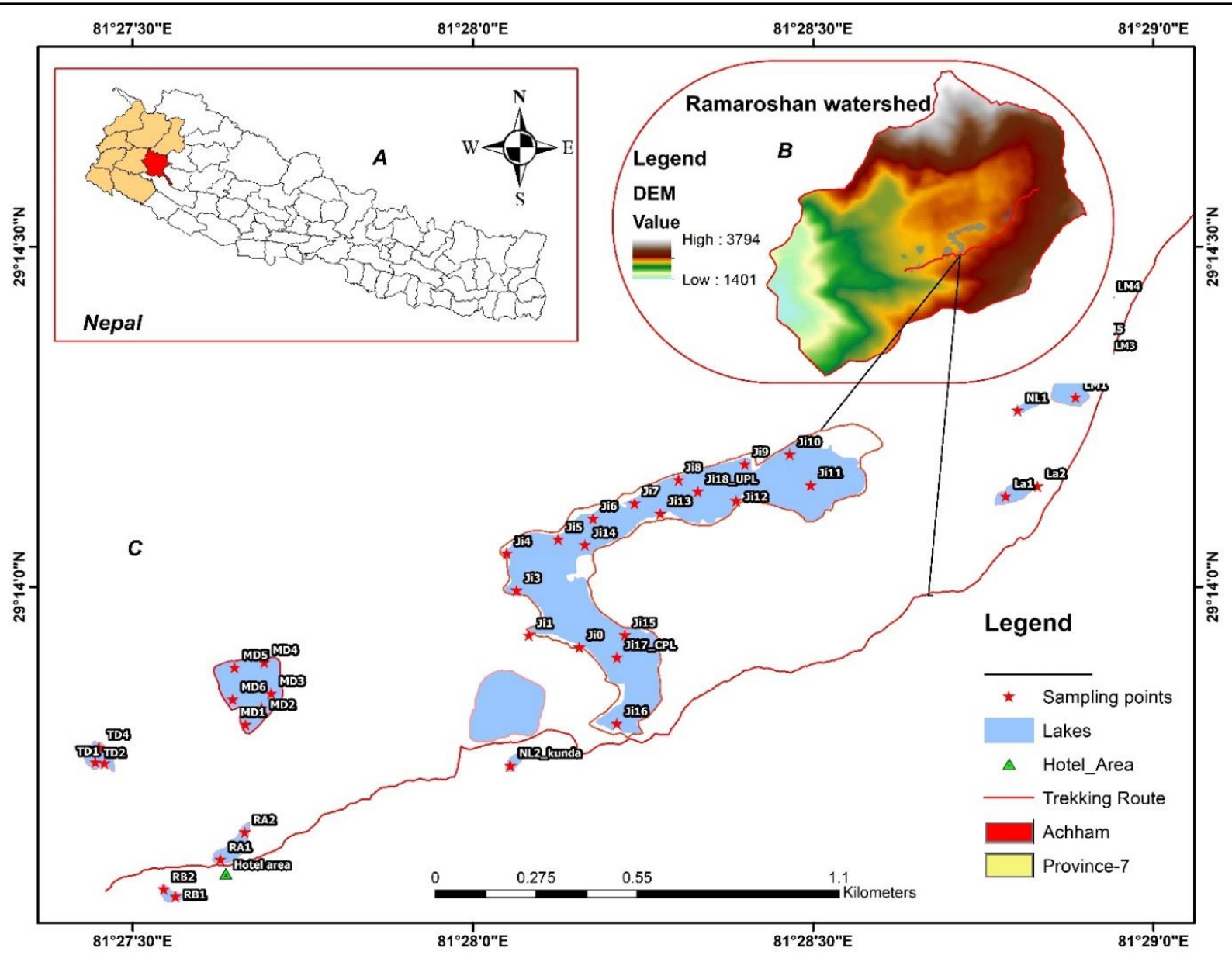

Figure 1 Figure showing the location of the study area in the map of Nepal (a); watershed map of the study area (b); and sampling locations in different lakes in the study area (c).

The data were analyzed by multivariate statistical analysis technique such as Spearman's correlation, principal component analysis (PCA) and cluster analysis (CA) with the help of Statistical Package for Social Sciences (SPSS) version 21.0. Piper plot was prepared with the help of RockWorks17 and water quality index was prepared with the help of $\mathrm{R}$ version 4.0.3.

\section{Results and Discussion}

\section{Bathymetry of major lakes}

The largest and deepest lake in RLCA is the Jingale Lake, with a maximum depth of $44 \mathrm{~m}$ (Table 1), followed by Batula Lake (max depth, $15 \mathrm{~m}$ ) and Mathillo Dhaune (max. depth $9.5 \mathrm{~m}$ ). Secchi disk value showed the maximum transparency of $8 \mathrm{~m}$, $4.3 \mathrm{~m}$ and $3 \mathrm{~m}$ at Jingale, Batula and Mathilo Dhaune Lakes, respectively. One of the lakes, supposedly the third-largest based on the surface area, could not be sampled for bathymetry due to snow/ice cover at the time of sampling.

The Jingale Lake is an L-shaped narrow lake with an area of 20.92 ha situated at an altitude of $2410 \mathrm{~m}$ asl (Table 1; Fig. 2). There are small inlets to the lake in the northern part that originates from the outlet of Lamadaha Lake and Lisedaha Lake. It has only one outlet in the southwest part. This lake is surrounded by boulders, rocks, eroding debris, local footpath, and dense forest coverage on the west-north part, whereas other parts are surrounded by rocks and dense forest.

The Batula Lake is the second largest lake of the RLCA, with an area of 4.68 ha (Table1). It is more or less oval in shape (Fig. 3). There is an inlet in the north part of the lake originating from the outlet of Jingale Lake. It is situated at an elevation of 2405 masl. This lake has a local footpath zone all around except in the inlet area. Batula Lake has a similar land cover as the Jingale Lake.

The Mathilo Dhaune Lake is nearly circular in shape and is the fourth-largest lake of the RLCA with an area of 2.37 ha with a maximum depth of $9.5 \mathrm{~m}$ (Fig. 4). It lies at an elevation of 2320 masl. The inlet of the lake originates from the outlet of Batula Lake, but there is no surface outflow. The littoral zone of the lake has no vegetation and is covered by boulders and rocks up to15 $\mathrm{m}$ from the lake-edge. Beyond the rocky littoral zone, the lake is surrounded by dense forest. 


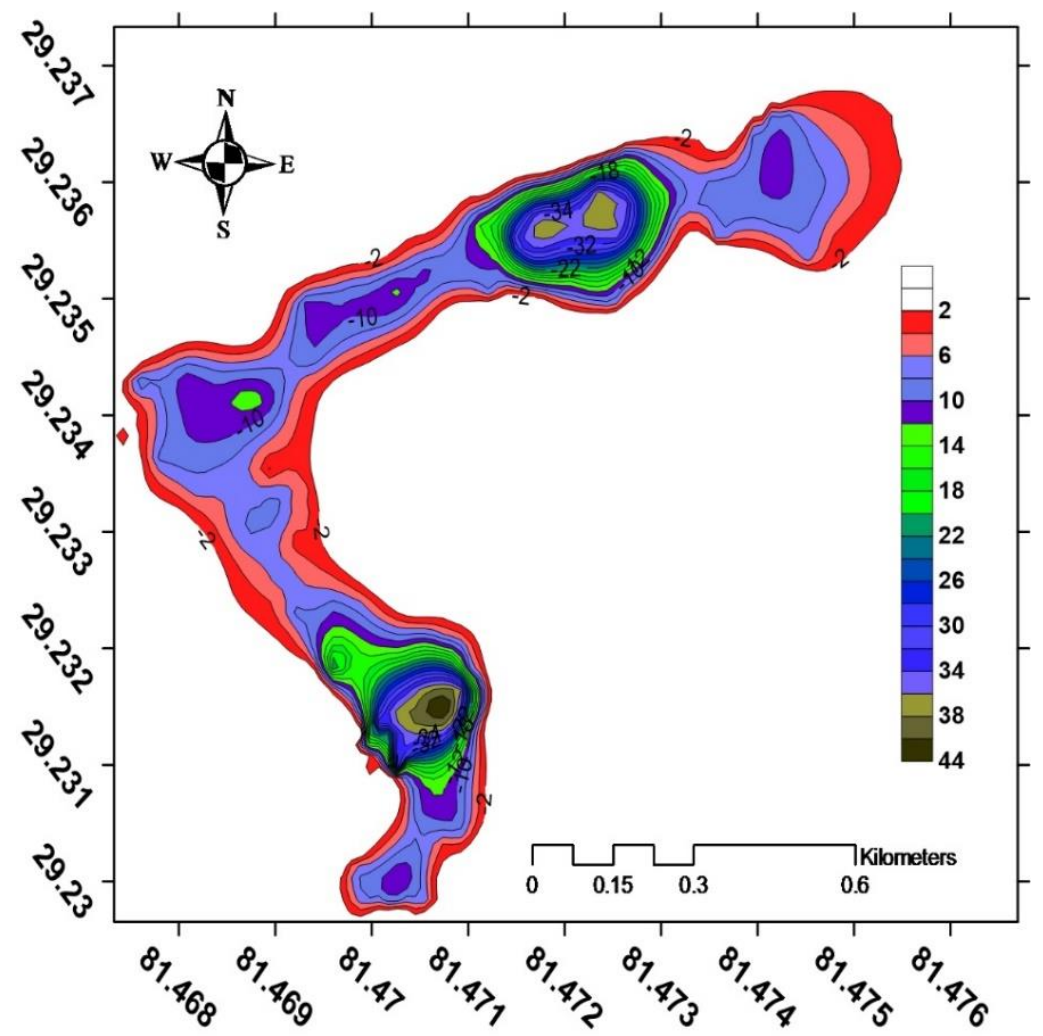

Figure 2 Bathymetry map of the Jingale Lake, one of the lakes in Ramaroshan Lake Complex

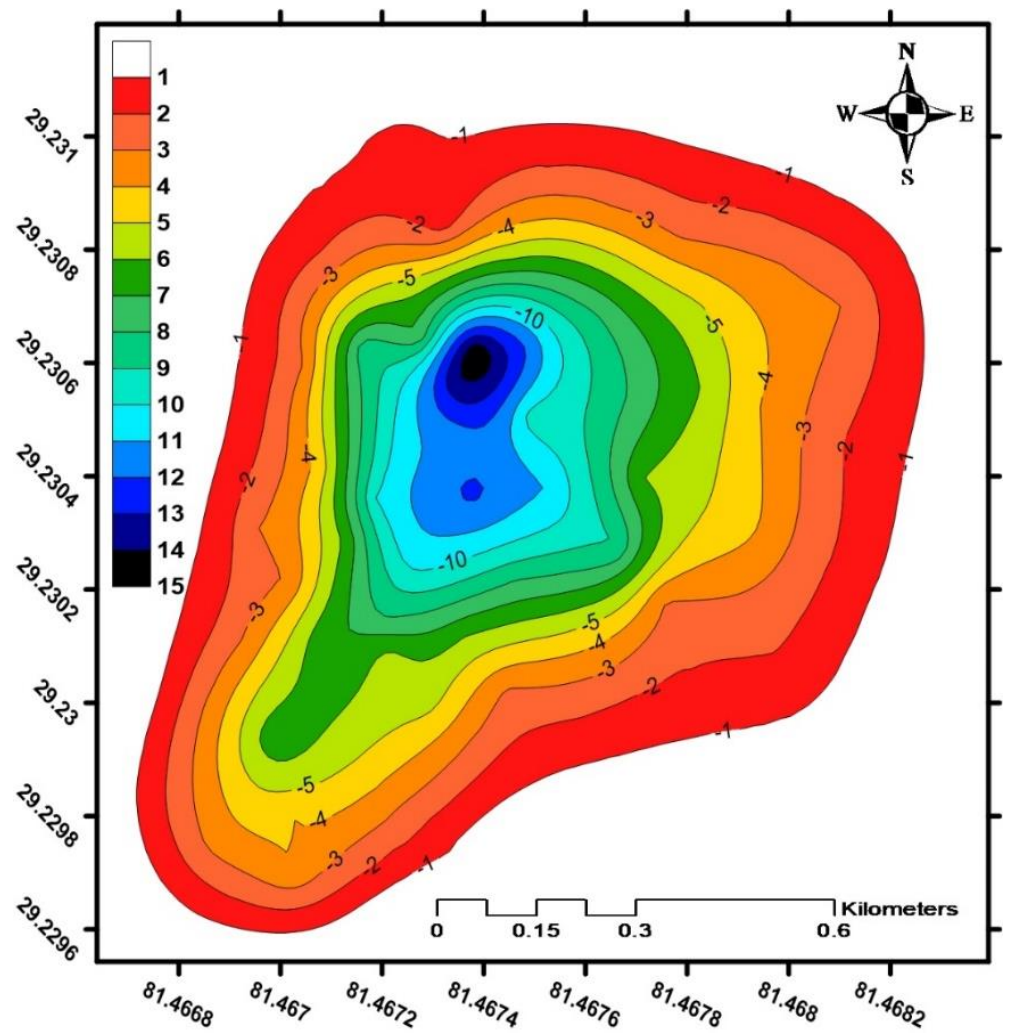

Figure 3 Bathymetry map of the Batula Lake, one of the lakes in the Ramaroshan Lake Complex. 


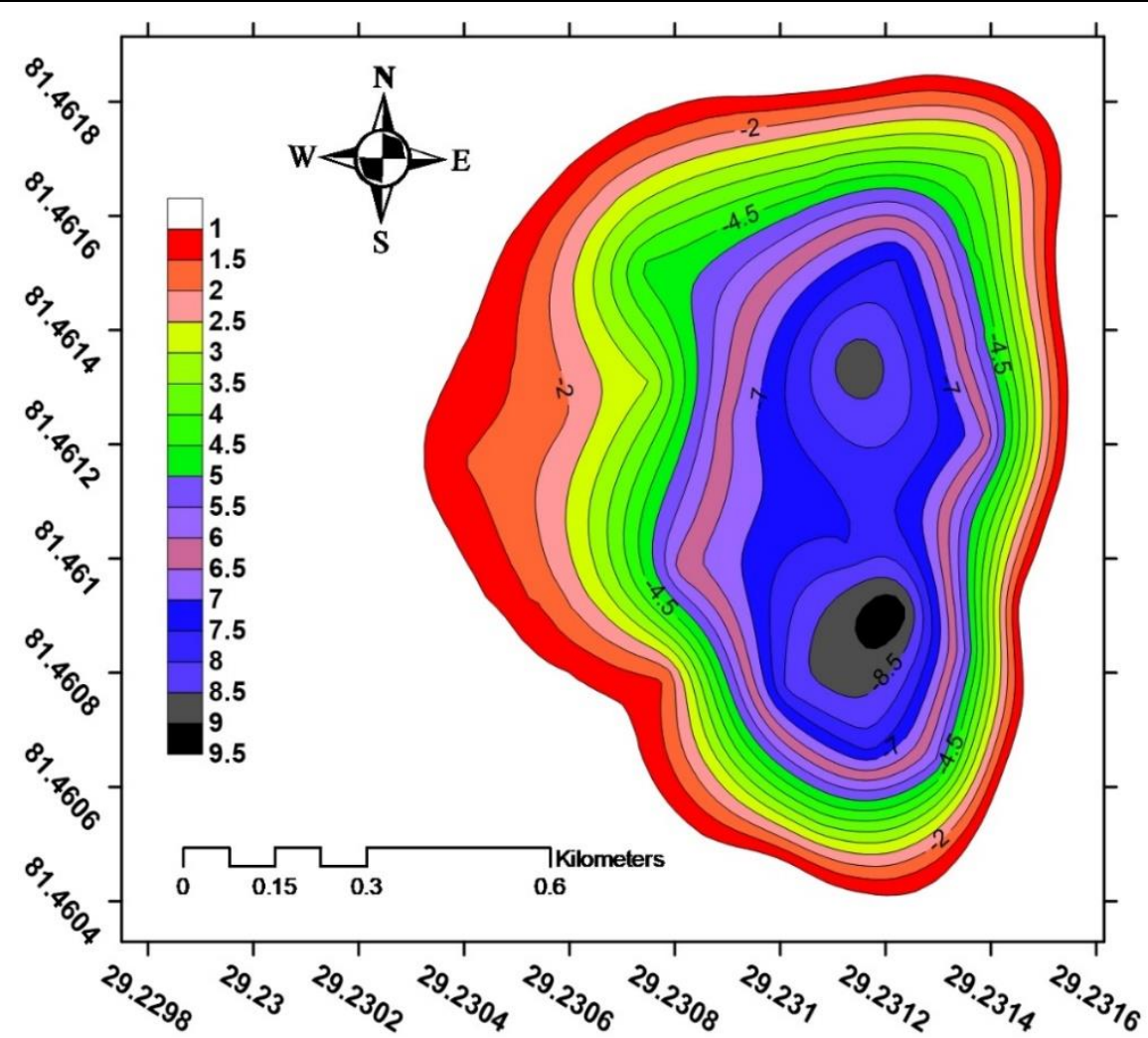

Figure 4 Bathymetry map of the Mathillo Dhaunne Lake, one of the lakes in the Ramaroshan Lake Complex.

Table 1 Morphometric measurement of three lakes in RLCA, Achham District, Nepal in January 2020

\begin{tabular}{|c|c|c|c|c|c|c|c|c|}
\hline Lake & $\begin{array}{l}\text { Area } \\
\text { (ha) }\end{array}$ & Coordinates & $\begin{array}{l}\text { Elevation } \\
\text { ( } \mathrm{m} \text { asl) }\end{array}$ & $\begin{array}{l}\text { Mean } \\
\text { Depth }\end{array}$ & SD & $\begin{array}{l}\text { Max. } \\
\text { Depth (m) }\end{array}$ & $\begin{array}{l}\text { Volume } \\
\left(\mathrm{m}^{3}\right)\end{array}$ & Status \\
\hline Jingale & 20.92 & $29^{\circ} 14^{\prime} 03.73^{\prime \prime N} ; 81^{\circ} 28^{\prime} 7.29^{\prime \prime E}$ & 2410 & 12.8 & 10.6 & 44.0 & 2692769.0 & Perennial \\
\hline Batula & 4.68 & $29^{\circ} 13^{\prime} 49.45^{\prime \prime N}$; $81^{\circ} 28^{\prime} 3.06^{\prime \prime} \mathrm{E}$ & 2405 & 8.0 & 3.6 & 15.0 & 375399.1 & Perennial \\
\hline Mathillo Dhaunne & 2.37 & $29^{\circ} 13^{\prime} 51.48^{\prime \prime} \mathrm{N} ; 8^{\circ} 27^{\prime} 40.33^{\prime \prime} \mathrm{E}$ & 2320 & 5.9 & 2.3 & 9.5 & 140515.9 & Perennial \\
\hline
\end{tabular}

\section{Water chemistry}

The summary of the 20 different water parameters is given in Table 2. The $\mathrm{pH}$ values ranged between 6.4 and 8.0, which lies within the guidelines recommended by NDWQI (GoN, 2005) and is also suitable for aquatic organisms. The water temperature of the lakes in RLCA is moderate that varies from $3.8^{\circ} \mathrm{C}$ to $15{ }^{\circ} \mathrm{C}$, identical to the regional temperature of the mid-hill areas during the winter season (Bhateria \& Jain, 2016).

Electrical conductivity (EC) in the present study ranged between $25 \mu \mathrm{S} / \mathrm{cm}$ and $193 \mu \mathrm{S} / \mathrm{cm}$, which is within the guideline value provided by GoN (2005). Generally, EC shows a significant correlation with many water parameters such as $\mathrm{pH}$, temperature, total hardness, calcium, total solids, total dissolved solids, iron concentration, and chemical oxygen demand (Bhateria \& Jain, 2016). The salinity in water bodies is contributed by the number of cations and anions such as $\mathrm{Ca}^{2+}$, $\mathrm{Mg}^{2+}, \mathrm{Cl}^{-}, \mathrm{NO}_{3}{ }^{-}, \mathrm{PO}_{4}{ }^{3}$ - and $\mathrm{HCO}_{3}$. Therefore, $\mathrm{EC}$ is also a good indicator of salinity changes in the lakes. The lentic water bodies receive dissolved solids from various sources such as runoff, urban runoff and soil erosion (Kent \& Belitz, 2004). In the present study, the total dissolved solids (TDS) ranged from $12 \mathrm{mg} / \mathrm{L}$ to $100 \mathrm{mg} / \mathrm{L}$. If TDS exceeds $500 \mathrm{mg} / \mathrm{L}$, it indicates hard water bodies not suitable for aquatic life. In addition, such water bodies pose a serious threat to kidney and heart disease patients (Al-hadithi, 2012). EC and TDS were in the order of Lamadaya $>$ Jingale $>$ Mathilo Dhaunne $>$ Tallo Dhaune $>$ Lisedali $>$ New lakes $(1,2)>$ Rame Daha A $>$ Rame Daha B, respectively.

DO is one of the key factors in determining the health of water bodies. In the present study, DO values ranged from 7 . $4 \mathrm{mg} / \mathrm{L}$ to $9.72 \mathrm{mg} / \mathrm{L}$, which is suitable for aquatic organisms. The mean value of DO in the present study is comparable to Rara Lake, which is higher than post-monsoon and lower than pre-monsoon season (Gurung et al., 2018); it might be due to the season of sampling (winter season in the present study) and availability of more macrophytes in lakes of RLCA. There 
is variability in concentrations of DO among the lakes in RLCA with higher in Mathillo Dhaune followed by Tallo Dhaune, Jingale, and Rame Daha. Such variability among the studied lakes could be due to the difference in sampling hours. The mean concentration of $\mathrm{NO}_{3}{ }^{-}, \mathrm{PO}_{4}{ }^{3-}, \mathrm{NH}_{4}$, and $\mathrm{SO}_{4}{ }^{2-}$ were observed within the range of recommendation by (WHO, 2011; NDWQS, 2005).

The turbidity in the present study varied from 0.1 NTU to 14 NTU, which is suitable for aquaculture (Shahzad et al., 2018). Turbidity gives an idea of the suspended particles in the water bodies that can affect physical, chemical, and biological conditions mainly by controlling light penetration and water temperature (Srivastava et al., 2011). The concentration of $\mathrm{CO}_{2}$ in the present study ranged from 2.2 to $6.6 \mathrm{mg} / \mathrm{L}$, which is suitable for the aquatic organism as well as within the range prescribed by WHO (2011).

\section{Major ions}

The overall summary of major ions in this study is presented in Table 3 which shows a decreasing order as $\mathrm{Ca}^{2+}>\mathrm{Mg}^{2+}>$ $\mathrm{Na}^{+}>\mathrm{K}^{+}$for cations and $\mathrm{HCO}_{3}^{-}>\mathrm{Cl}^{-}>\mathrm{SO}_{4}{ }^{2-}>\mathrm{PO}_{4}^{2-}>$ $\mathrm{NO}_{3}{ }^{-}$for anions, respectively. The comparison of the mean concentration of major ions in the present study with previous studies from Rara Lake (2990 masl), Gokyo Lake (5000 masl) and Gosaikunda Lake (4700 masl), Paanch Pokhari, and Langtang Valley lakes are given in Table 3. The comparison of the relative ionic proportion of selected freshwater bodies with the present study revealed that the parameter, such as $\mathrm{Na}^{+}$, was the most dominant cations in the study area. The dominance of $\mathrm{Na}^{+}$in water bodies might be due to the silicate weathering from surrounding rocks and the ion exchange process in water bodies (Kumar et al., 2019; Mallick, 2017). Therefore, this warrants further study in this direction.

The decreasing or increasing concentrations of different parameters in order such as $\mathrm{SO}_{4}^{2-}<\mathrm{Ca}^{2+}$ and $\mathrm{Na}^{+}>\mathrm{Mg}^{2+}>$ $\mathrm{K}^{+}>\mathrm{HCO}_{3}^{-}>\mathrm{Cl}^{-}$are probably due to differences in their geological settings and anthropogenic activities. The overall comparison of the previous study (Table 3) has shown that the Gokyo, Paanch Pookhari and Gosaikunda Lakes have a similar type of parameters except for $\mathrm{Cl}^{-}$in Gosaikunda Lake, but the Rara Lake, Langtang valley and Ramaroshan Lake cluster also has a similar type of parameter except for $\mathrm{Na}^{+}$in Ramaroshan lake cluster.

Table 2 Summary of the physico-chemical parameters of lake waters in the Ramaroshan Lakes Area.

\begin{tabular}{|c|c|c|c|c|c|c|}
\hline Parameters & Max & Min & SD & Mean & NDWQS & WHO (2011) \\
\hline $\mathrm{pH}$ & 8.01 & 6.4 & 0.20 & 6.9 & $6.5-8.5$ & $6.5-8.5$ \\
\hline $\mathrm{EC}$ & 193 & 25 & 36.71 & 77.41 & 1500 & 1500 \\
\hline TDS & 100 & 12 & 19.02 & 40.02 & 1000 & 1000 \\
\hline Temp & 15 & 3.8 & 2.84 & 8.52 & 20 & 20 \\
\hline $\mathrm{DO}$ & 9.72 & 7.4 & 0.69 & 8.36 & -- & 6 \\
\hline $\mathrm{K}^{+}$ & 3.6 & 0.08 & 0.77 & 1.34 & -- & 10 \\
\hline $\mathrm{Na}^{+}$ & 6.1 & 5.1 & 0.23 & 5.6 & -- & 200 \\
\hline Turbidity & 14 & 0.1 & 2.07 & 0.85 & -- & -- \\
\hline $\mathrm{NO}_{3}^{-}$ & 0.07 & 0.04 & 0.008 & 0.04 & 50 & 10 \\
\hline $\mathrm{PO}_{4}^{2-}$ & 0.24 & 0.1 & 0.027 & 0.158 & -- & 1 \\
\hline $\mathrm{NH}_{4}$ & 0.29 & 0.064 & 0.065 & 0.12 & -- & 0.5 \\
\hline $\mathrm{SO}_{4}^{2-}$ & 3.36 & 0.05 & 0.62 & 1.04 & 250 & 250 \\
\hline $\mathrm{Cl}^{-}$ & 21.3 & 2.83 & 3.91 & 11.83 & 250 & 250 \\
\hline Total Hardness & 110 & 16 & 19.03 & 44.11 & 500 & 500 \\
\hline Mg-Hardness & 36 & 4 & 6.38 & 14 & -- & 250 \\
\hline $\mathrm{Ca}-H a r d n e s s$ & 86 & 8 & 16.91 & 29.69 & -- & 250 \\
\hline $\mathrm{Ca}^{2+}$ & 34.4 & 3.2 & 3.2 & 6.76 & 200 & 75 \\
\hline \multirow[t]{2}{*}{$\mathrm{Mg}^{2+}$} & 8.784 & 0.97 & 1.55 & 3.41 & -- & 30 \\
\hline & 145 & 10 & 23.98 & 43.58 & -- & 120 \\
\hline Free $\mathrm{CO}_{2}$ & 6.6 & 2.2 & 1.61 & 3.32 & -- & 6 \\
\hline
\end{tabular}

Note: $\left\{\right.$ Units of all the variables are $\mathrm{mg} / \mathrm{L}$, except $\mathrm{pH}, \mathrm{WT}\left({ }^{\circ} \mathrm{C}\right)$, and $\left.\mathrm{EC}(\mu \mathrm{S} / \mathrm{cm})\right\}$

Table 3 Comparison among different major ions concentration of Ramaroshan lake and previous studies from mid-hill and highaltitude lakes in Nepal

\begin{tabular}{|c|c|c|c|c|c|c|c|c|}
\hline Lakes & $\mathrm{Na}^{+}$ & $\mathbf{M g}^{2+}$ & $\mathbf{K}^{+}$ & $\mathrm{Ca}^{2+}$ & $\mathrm{Cl}^{-}$ & $\mathrm{SO}_{4}{ }^{2-}$ & $\mathrm{HCO}_{3}^{-}$ & References \\
\hline Ramaroshan lakes & $5.6 \pm 0.23$ & $3.41 \pm 1.55$ & $1.34 \pm 0.77$ & $6.76 \pm 3.2$ & $11.83 \pm 3.91$ & $1.04 \pm 0.62$ & $43.58 \pm 23.98$ & Present study \\
\hline Lake Rara & $0.35 \pm 0.19$ & $5.89 \pm 3.65$ & $0.80 \pm 0.51$ & $9.17 \pm 2.67$ & $0.10 \pm 0.05$ & $0.14 \pm 0.09$ & $54.02 \pm 23.5$ & (Gurung et al., 2018) \\
\hline Gokyo Lakes & $0.9 \pm 0.22$ & $0.4 \pm 0.03$ & $0.6 \pm 0.06$ & $5.13 \pm 0.91$ & $0.2 \pm 0.05$ & $4.3 \pm 1.15$ & $17 \pm 2.24$ & (Lacoul \& Freedman, 2006) \\
\hline Paanch Pokhari & $0.31 \pm 0.24$ & $0.2 \pm 0.11$ & $0.22 \pm 012$ & $1 \pm 0.4$ & $3.5 \pm 1.39$ & $4.2 \pm 1.3$ & $13.9 \pm 13$ & (Raut et al., 2017) \\
\hline Gosainkunda Lake & $0.5 \pm 5.44$ & $1.30 \pm 0.7$ & $0.3 \pm 0.07$ & $3.5 \pm 2.05$ & $20.50 \pm 14$ & $3.94 \pm 2.4$ & $17.5 \pm 3.3$ & (Raut et al., 2013) \\
\hline Langtang Valley & $1.9 \pm 1.3$ & $1.64 \pm 1.3$ & $2.08 \pm 1.5$ & $10.77 \pm 5.53$ & $8.24 \pm 2.3$ & $5 \pm 5.31$ & $36.63 \pm 15.2$ & (Tuladhar et al., 2015) \\
\hline
\end{tabular}


Correlation analysis has been widely used to understand the interrelation between the physicochemical parameters. The result shows that EC and TDS have a strong significant correlation with each other as well as total hardness (TH), Cahardness $(\mathrm{Ca}-\mathrm{H})$ and $\mathrm{Ca}^{2+}(p<0.01)$. This shows that $\mathrm{Ca}-\mathrm{H}$ and $\mathrm{Ca}^{2+}$ have the similar source and contribute for the EC, TDS and TH. The result also identified the significant correlation of total alkalinity with EC, TDS, TH, Ca-H, and $\mathrm{Ca}^{2+}$ at $(p<0.01)$. This indicates a similar source of $\mathrm{TH}$, total alkalinity, EC and TDS along with $\mathrm{Mg}^{2+}$ and $\mathrm{Ca}^{2+}$ ions.

PCA results are plotted in Fig. 5, loading values, and component matrix was used to understand and identify the controlling factors of water chemistry in RLCA.

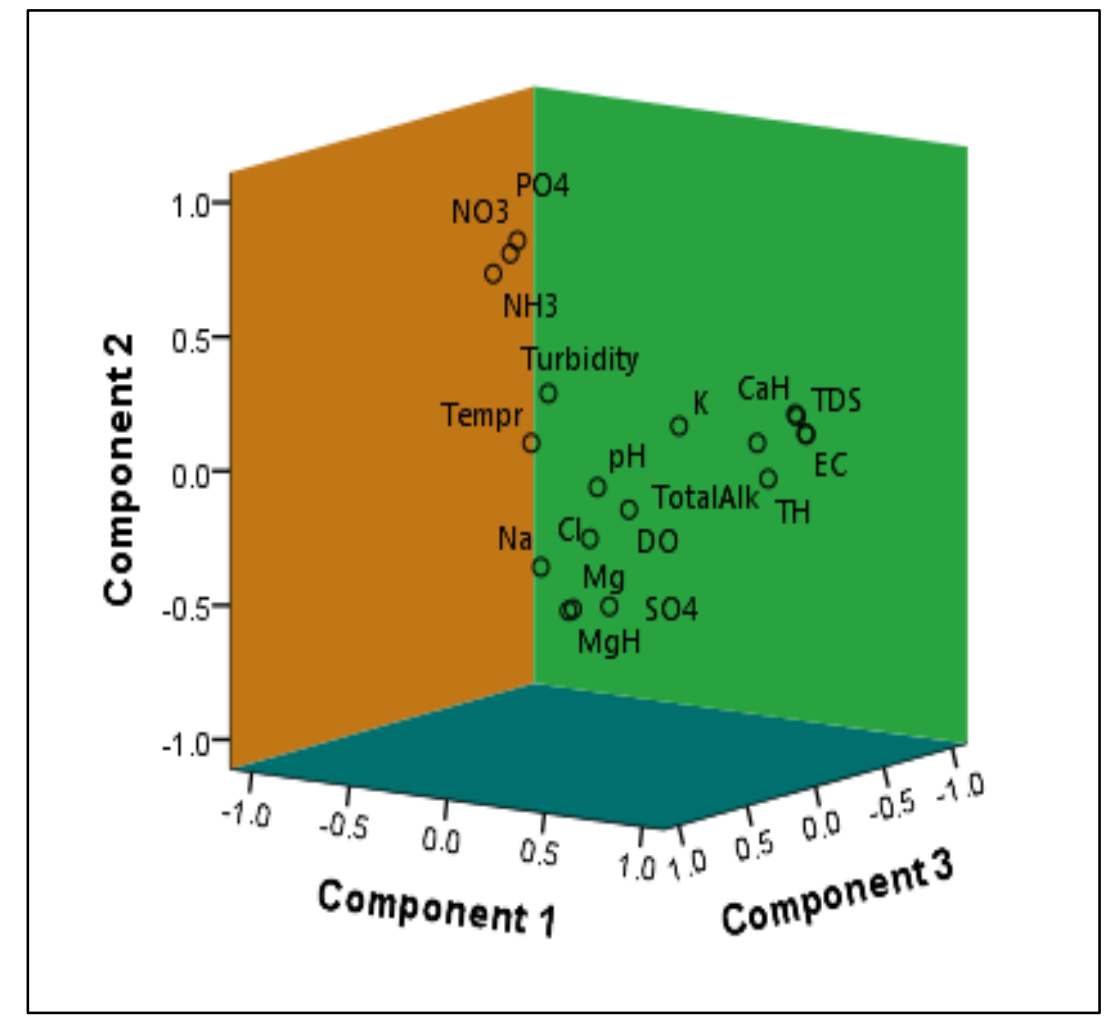

Figure 5 Plot showing principal component analysis (PCA) of physico-chemical parameters in the Ramaroshan Lake Complex

Loading factors are classified into three different categories such as strong $>0.75$, moderate $>0.75-0.50$ and weak $>0.50$ 0.30 , respectively (Lui et al., 2003) with eigenvalues $\geq 1.0$ consider as significant (Sharma \& Tiwari, 2018). PC1 explained $30.52 \%$ of the variance having strong loading factors such as EC, TDS, TH, Ca-H, and $\mathrm{Ca}^{2+}$; and with moderate loading of total alkalinity $\left(\mathrm{HCO}_{3}{ }^{-}\right)$. These factors are mainly contributed by natural sources from the carbonate weathering and lithology of the study area. Similarly, PC2 explained $15.79 \%$ of the total variance with a strong loading factor of $\mathrm{PO}_{4}{ }^{2-}$ and $\mathrm{NO}_{3}{ }^{-}$, probable sources being the debris and organic matters. Other PCs have no strong loading factors showing less governance over the water chemistry.

From the wards linkage based dendrogram diagram (McKenna, 2003) (Fig. 6), 43 samples are grouped into distinct 3 clusters. Cluster 1 is composed of $62.79 \%$ of total samples (include 11 sites from Jingale, all sites from Tallo Dhaune, Mathilo Dhaune and Rame DahaA, and one site each from
Lisedali, New Lake1, and Rame DahaB) having higher concentrations of EC, TDS, TH, Ca and total alkalinity compared to the sites in Cluster 2 and lower than Cluster 3. Similarly, Cluster 2 is composed of $32.56 \%$ (include seven sites from Jingale, four sites from Lamadaya, and one site each from New Lake 2, Lisedali, and Rame Daha B), and Cluster 3 is composed of $4.66 \%$ (include single sites from Jingale and Lamadaya). On the basis of the concentration of parameters in samples, the pollution status of clusters can be ordered as Cluster $2<$ Cluster $1<$ Cluster 3, which indicates that Cluster 2 is least polluted than other clusters. The cluster 1 and 3 are slightely polluted than cluster 2 , might be due to high human disturbance, high wildlife recreational activities, eutrophication, presence of algal blooms and anthropic activities like recreation (Pant et al., 2019).

\section{Water quality index (WQI)}

The water quality index (WQI) can be categorized into five different classes (Brown et al., 1972). Out of 9 lakes, three 
lakes had the lower WQI value (25) with excellent water quality, whereas the remaining six lakes had good (slightly polluted) water quality with WQI ranging from 26-32 (Fig. 7). This explanation is also supported by the mean concentration of $\mathrm{SO}_{4}{ }^{2-}, \mathrm{NO}_{3}, \mathrm{TH}$, and free $\mathrm{CO}_{2}$, which were higher in the lakes with higher WQI values. In overall rating, the WQI value of lakes in RLCA was indicating good water quality with a slightly polluted status.

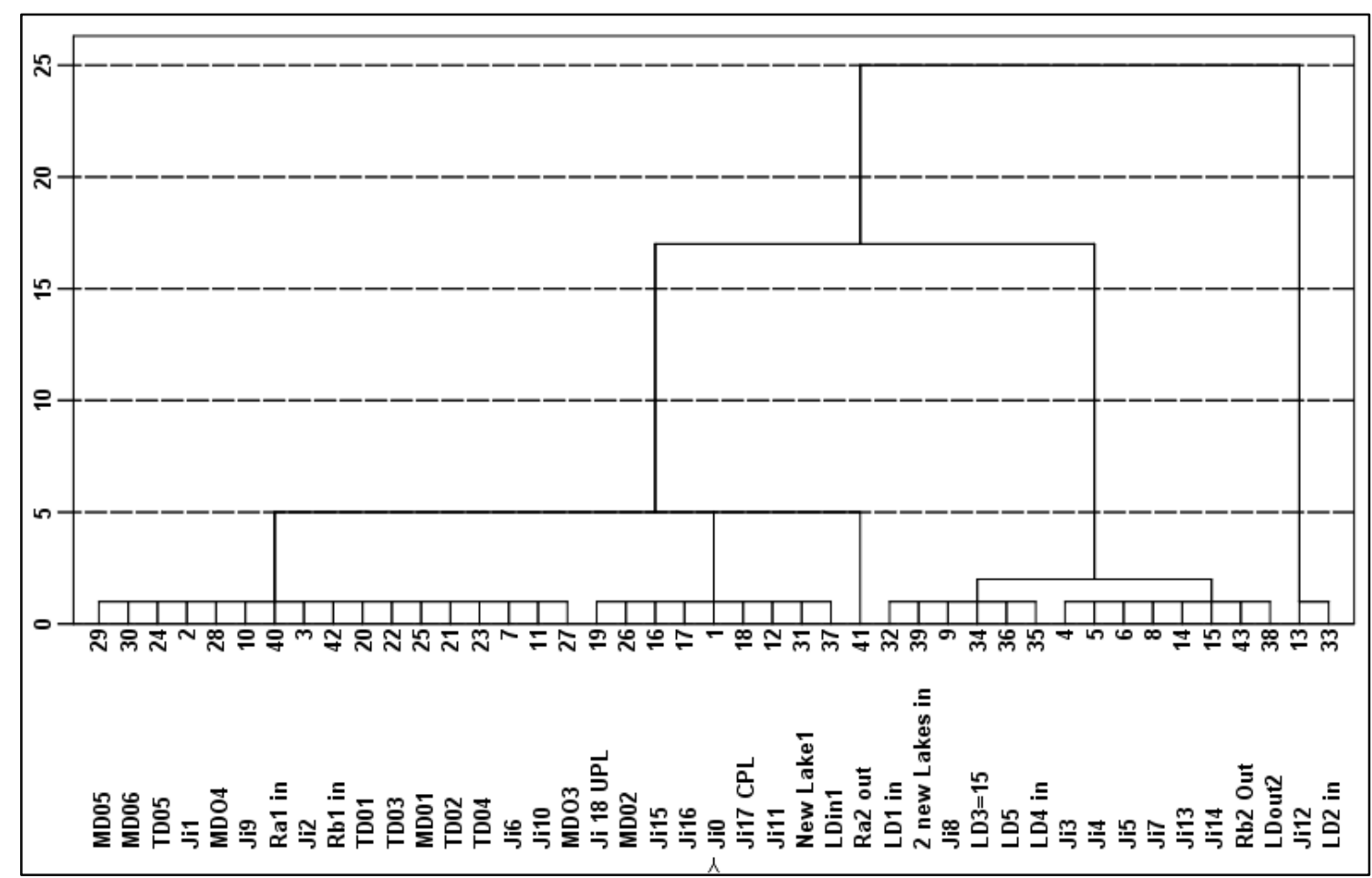

Figure 6 Hierarchical cluster analysis based on wards linkage method

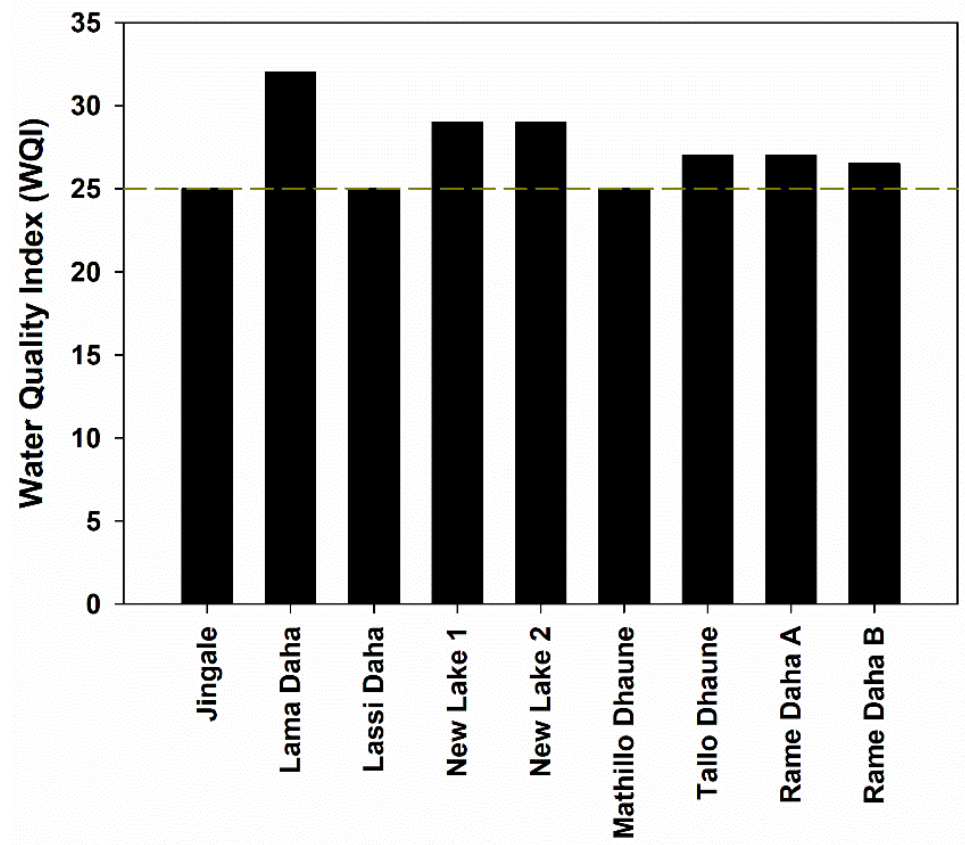

Figure 7 Plot showing the WQI values of Ramaroshan Lake Complex. 


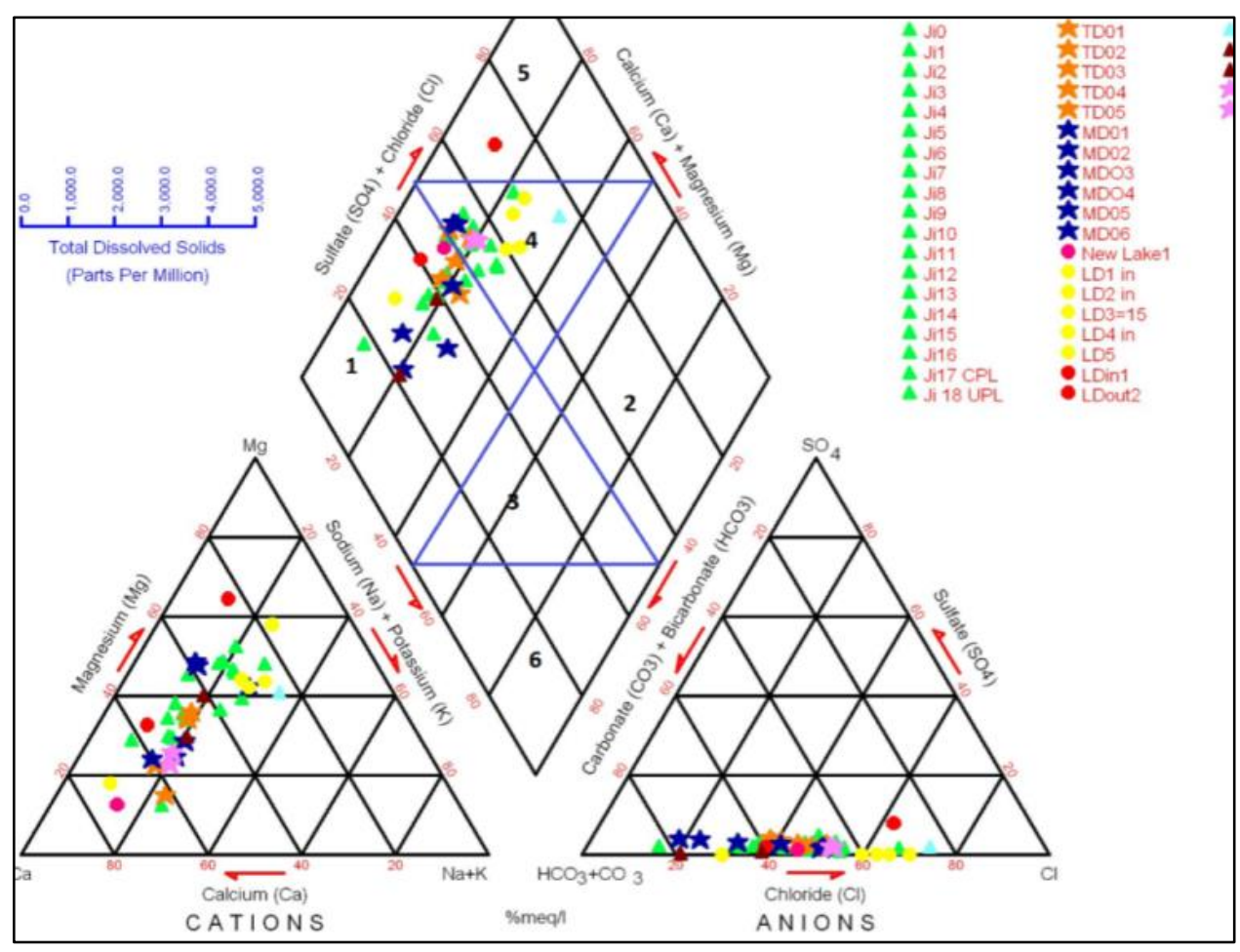

Figure 8 Piper Trilinear diagram classify the hydrochemical properties of the water of the lake

The hydrochemical properties of the RLCA are presented in the trilinear diagram (Fig. 8), which is an effective procedure to segregate the concentration of major cations $\mathrm{Ca}^{2+}, \mathrm{Mg}^{2+}$, $\mathrm{Na}^{+}, \mathrm{K}^{+}$and anions $\mathrm{HCO}_{3}{ }^{-}, \mathrm{SO}_{4}{ }^{2-}, \mathrm{Cl}^{-}$for understanding sources of these dissolved constituents in water (Piper, 1944; Ravikumar et al., 2015).

The water type can be classified into six classes in the piper diagram (Fig. 8): 1) $\mathrm{Ca}_{-} \mathrm{HCO}_{3}, 2$ ) Na-Cl, 3) Mixed Ca-Na$\mathrm{HCO}_{3}$, 4) Mixed $\left.\mathrm{Ca}-\mathrm{Mg}-\mathrm{Cl}, 5\right) \mathrm{Ca}-\mathrm{Cl}$, and 6) $\mathrm{Na}-\mathrm{HCO}_{3}$. In the present study, about $58 \%$ of samples belong to $\mathrm{Ca}-\mathrm{Mg}-\mathrm{Cl}$ mixed type whereas $41 \%$ to $\mathrm{Ca}-\mathrm{HCO}_{3}$ type. Also, from the plot, it revealed that alkaline earth metals $(\mathrm{Ca}+\mathrm{Mg})$ are dominant over alkali metals $(\mathrm{Na}+\mathrm{K})$ with the dominant of $\mathrm{HCO}_{3}$ and $\mathrm{Cl}$ acids. The results suggest the carbonate weathering in the studied area. Similar findings have also been reported in nearly located high mountain Rara Lake (Gurung et al., 2018).

\section{Conclusion}

The study of morphometric characteristics and physicochemical parameters was accomplished for the first time in the RLCA, mid-hill, far-west Nepal. The physico-chemical parameters of the lake waters were within the guidelines of WHO and NDWQS. $\mathrm{Ca}^{2+}$ and $\mathrm{HCO}_{3}$ were the dominant cation and anion, respectively, indicating higher carbonate weathering of surrounding rocks as the dominant sources of major ions. The piper diagram has shown dominance of earth alkaline metal such as $\mathrm{Ca}^{2+}+\mathrm{Mg}^{2+}>\mathrm{Na}^{+}+\mathrm{K}^{+}$and acidic anions metal such as $\mathrm{SO}_{4}^{2-}+\mathrm{Cl}^{-}>\mathrm{Na}^{+}+\mathrm{K}^{+}$, respectively. The PCA analysis showed that EC, TDS, TH, $\mathrm{Ca}^{2+}$, and $\mathrm{HCO}_{3}$ were strong loading factors, which demonstrates the high contribution of lithology in the study area. The WQI indicated that the water qualities of RLCA were in good condition (i.e., only slightly polluted).

\section{Acknowledgements}

We would like to thank Mr. Ramesh Basnet, Mr. Sagar Rokaya and Mr. Parkash Saud for assisting the field data collection and analysis. Our special thanks go to all the local residents of the study area for their valuable cooperation. This study is partially funded by the project through Higher Education Reform Project (HERP-DLI-7B) at Tribhuvan University to the last author.

\section{References}

Al-hadithi, M. (2012). Application of water quality index to assess suitability of groundwater quality for drinking purposes in Ratmao-Pathri Rao watershed, Haridwar District, India. American Journal of Scientific and Industrial Research, 3(6), 395-402.

Awulachew, S.B. (2006). Investigation of physical and bathymetric characteristics of Lakes Abaya and Chamo, Ethiopia, and their management implications. Lakes \& Reservoirs: Science, Policy and Management for Sustainable Use, 11(3), 133-140. 
Bhateria, R., \& Jain, D. (2016). Water quality assessment of lake water: A review. Sustainable Water Resources Management, 2(2), 161-173.

Bhuju, D.R., Sharma, S., Jha, P.K., \& Gaire, N.P. (2013). Scientific Discourse of Lakes in Nepal. Nepal Journal of Science and Technology, 13(2), 147-158.

BIS. (2012). Indian standards drinking water specifications IS 10500:2012. Bureau of Indian Standard, Manak Bhawan, New Delhi, India.

Bora, M., \& Goswami, D.C. (2017). Water quality assessment in terms of water quality index (WQI): Case study of the Kolong River, Assam, India. Applied Water Science, 7, 3125-3135.

Brown, R.M., McClelland, N.I., Deininger, R.A., \& O’Connor, M.F. (1972). A water quality index- crashing the psychological barrier. In W.A. Thomas (Ed.), Indicators of environmental quality, pp. 173-182.

Cheng, G., Li, X., Zhao, W., Xu, Z., Feng, Q., Xiao, S., \& Xiao, H. (2014). Integrated study of the waterecosystem-economy in the Heihe River Basin. National Science Review, 1(3), 413-428.

Dahal, B.K., \& Dahal, R.K. (2017). Landslide hazard map: Tool for optimization of low-cost mitigation. Geoenvironmental Disasters, 4(1), 8. doi 10.1186/s40677-0170071-3.

DOF. (2017). Wetlands of Western Nepal: A Brief Profile of Selected Lakes. Ministry of Forests and Soil Conservation. Department of Forests, Nepal.

Eaton, A.D., Clesceri, L.S., Rice, E.W., Greenberg, A.E., \& Franson, M.A.H. (Eds.) (2005). Standard Methods for the Examination of $W$ ater \& $W$ astewater, Centennial Edition (21 edition). American Public Health Association.

George, G., Hurley, M., \& Hewitt, D. (2007). The impact of climate change on the physical characteristics of the larger lakes in the English Lake District. Freshwater Biology, 52(9), 1647-1666.

Gibbs, J.P. (2000). Wetland Loss and Biodiversity Conservation. Conservation Biology, 14(1), 314-317.

GoN. (2005). National Drinking Quality Standards and Directives, 2005 (p. 22). Ministry of Physical Planning and Works. Government of Nepal.

Gurung, S., Gurung, A., Sharma, C.M., Jüttner, I., Tripathee, L., Bajracharya, R.M., Raut, N., Pradhananga, P., Sitaula, B.K., Zhang, Y., Kang, S., \& Guo, J. (2018). Hydrochemistry of Lake Rara: A high mountain lake in western Nepal. Lakes \& Reservoirs: Research \& Management, 23(2), 87-97.

Håkanson, L. (2005). The importance of lake morphometry and catchment characteristics in limnology - ranking based on statistical analyses. Hydrobiologia, 541, 117-137.

Hushulong, Q. (2012). The problems of wetlands in our country and the researches. Energy Procedia, 17, 462-466.

Karki, J.B., Shrestha, K., \& Khanal, B. (2002). Faunal diversity and related conservation issues at Badimalika region (Achham, Bajura and Kalikot districts), Nepal. The Wildlife, 14-22.
Kent, R., \& Belitz, K. (2004). Concentrations of Dissolved Solids and Nutrients in Water Sources and Selected Streams of the Santa Ana Basin, California, October 1998-September 2001. National Water Quality Assessment Program, Report \# 03-4326.

Kumar, R., Singh, S., \& Sharma, R.C. (2019). Application of WQI for assessment of water quality of high altitude lake Dodi Tal, Garhwal Himalaya, India. Sustainable Water Resources Management, 5(3), 1033-1042.

Lacoul, P., \& Freedman, B. (2006). Recent Observation of a Proliferation of Ranunculus trichophyllus Chaix. In Highaltitude Lakes of the Mount Everest Region. Arctic, Antarctic, and Alpine Research, 38(3), 394-398.

Lamsal, P., Pant, K.P., Kumar, L., \& Atreya, K. (2015). Sustainable livelihoods through conservation of wetland resources: A case of economic benefits from Ghodaghodi Lake, western Nepal. Ecology and Society, 20(1), doi 10.5751/ES-07172-200110.

Liu, C.W., Lin, K.H., \& Kuo, Y.-M. (2003). Application of factor analysis in the assessment of groundwater quality in a Blackfoot disease area in Taiwan. Science of the Total Environment, 313, 77-89.

Mallick, J. (2017). Hydrogeochemical characteristics and assessment of water quality in the Al-Saad Lake, Abha Saudi Arabia. Applied Water Science, 7(6), 2869-2882.

McKenna, J.E. (2003). An enhanced cluster analysis program with bootstrap significance testing for ecological community analysis. Environmental Modelling \& Software, 18(3), 205-220.

Moses, S.A., Janaki, L., Joseph, S., Justus, J., \& Vimala, S.R. (2011). Influence of lake morphology on water quality. Environmental Monitoring and Assessment, 182(1), 443-454.

Nõges, T. (2009). Relationships between morphometry, geographic location and water quality parameters of European lakes. Hydrobiologia, 633, 33-43.

Pant, R.R., Dhakal,T.M., Thapa, L.B., Baral, U., Dangol, A., Chalaune, T.B., Pal, K.B., (2019). Water quality assessment of the Betkot Lake, Sudurpaschim Province. North American Academic Research, 2(12), 36-62.

Piper, A.M. (1944). A graphic procedure in the geochemical interpretation of water analyses. Eos, Transactions American Geophysical Union, 25(6), 914-928.

Poudel, A.K., \& Adhikari, D. (2020). Monitoring of wetland dependent birds in Ramaroshan Lake Complex of Achham, Nepal. Bird Conservation Nepal Newsletter, 12-14.

Qiao, B., Zhu, L., \& Yang, R. (2019). Temporal-spatial differences in lake water storage changes and their links to climate change throughout the Tibetan Plateau. Remote Sensing of Environment, 222, 232-243.

Raut, R., Bajracharya, R.M., Sharma, S., Sharma, C.M., Kang, S., Zhang, Q., Tripathee, L., Chen, P., Rupakheti, D., Guo, J., \& Dongol, B.S. (2017). Potentially toxic trace metals in water and lake-bed sediment of Panchpokhari, an alpine lake series in the central Himalayan region of Nepal. Water, Air, \& Soil Pollution, 228(8), 303. 
Raut, R., Sharma, S., Bajracharya, R.M., Sharma, C.M., \& Gurung, S. (2013). Physico-chemical Characterization of Gosainkunda Lake. Nepal Journal of Science and Technology, 13(1), 107-114.

Ravikumar, P., Somashekar, R.K., \& Prakash, K.L. (2015). A comparative study on usage of Durov and Piper diagrams to interpret hydrochemical processes in groundwater from SRLIS river basin, Karnataka, India. Earth Science, 80, 31073-31077.

Schindler, D.W., Curtis, P.J., Parker, B.R., \& Stainton, M.P. (1996). Consequences of climate warming and lake acidification for UV-B penetration in North American boreal lakes. Nature, 379(6567), 705-708.

Shahzad, A., Kazmi, S.J.H., Farhan, S.B., Shaikh, S., Aziz, A., Khan, H.U.A., Ahmed, A.F., \& Ahmed, F. (2018). Mapping Turbidity Levels in the Lake's Water using Satellite Remote Sensing Technique. International Journal of Economic and Environmental Geology, 9(3), 40-43.

Sharma, C.M., Sharma, S., Bajracharya, R.M., Gurung, S., Jüttner, I., Kang, S., Zhang, Q., \& Li, Q. (2012). First results on bathymetry and limnology of high-altitude lakes in the Gokyo Valley, Sagarmatha (Everest) National Park, Nepal. Limnology, 13(1), 181-192.

Sharma, C.M., Sharma, S., Borgstrom, R., \& Bryceson, I. (2005). Impacts of a small dam on macroinvertebrates: A case study in the Tinau River, Nepal. Aquatic Ecosystem Health \& Management, 8(3), 267-275.
Sharma, R.C., \& Tiwari, V. (2018). Seasonal physico-chemical characterization of water of sacred lake Nachiketa Tal, Garhwal Himalaya. Applied Water Science, 8(6), 164.

Srivastava, P.K., Mukherjee, S., Gupta, M., \& Singh, S.K. (2011). Characterizing monsoonal variation on water quality index of River Mahi in India using geographical information system. Water Quality, Exposure and Health, 2(3), 193-203.

Stefanidis, K., \& Papastergiadou, E. (2012). Relationships between lake morphometry, water quality, and aquatic macrophytes, in Greek lakes. Fresenius Environmental Bulletin, 21(10a), 3018-3026.

Tuladhar, A., Kayastha, R.B., Gurung, S., \& Shrestha, A. (2015). Hydrochemical characterization of glacial meltwaters draining from Langtang valley, Nepal. Journal of Water Resource and Protection, 7(8), 605-613.

Upadhayaya, P.K. (2019). Tourism Stimulated Prosperity and Peace in Provincial Destination: An Appraisal of Far West Nepal. Journal of Tourism and Hospitality Education, 9, 30-39.

WHO. (2011). World Health Statistics, 2011. World Health Organization.

Zedler, J.B., \& Kercher, S. (2005). Wetland resources: Status, trends, ecosystem services, and restorability. Annual Review of Environment and Resources, 30(1), 39-74. 